\title{
Clinical characteristics of 41 patients with pneumonia due to 2019 novel coronavirus disease (COVID-19) in Jilin, China
}

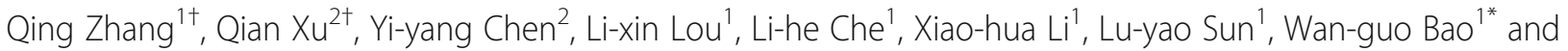
$\mathrm{Na} \mathrm{Du}{ }^{1 *}$

\begin{abstract}
Background: The clinical characteristics of patients with confirmed 2019 novel coronavirus disease (COVID-19) in Jilin Province, China were investigated.

Methods: Clinical, laboratory, radiology, and treatment data of 41 hospitalized patients with confirmed COVID-19 were retrospectively collected. The population was stratified by disease severity as mild, moderate, or severe, based on guidelines of the National Health and Medical Commission of China.

Results: The 41 hospitalized patients with COVID-19 were studied, and the median age was 45 years (interquartile range [IQR], 31-53; range, 10-87 years) and 18 patients (43.9\%) were female. All of the patients had recently visited Wuhan or other places (ie, Beijing, Thailand) or had Wuhan-related exposure. Common symptoms included fever (32[78\%]) and cough (29[70.7\%]). All patients were without hepatitis B/C virus hepatitis. CRP (C-reactive protein, 11.3 $\mathrm{mg} / \mathrm{L}$ [interquartile range $\{\mid \mathrm{QR}\}, 2.45-35.2])$ was elevated in 22 patients $(53.7 \%)$, and cardiac troponin I $(1.5 \mathrm{ng} / \mathrm{mL}$ [IQR, 0.8-5.0]) was elevated in 41 patients (100\%). Chest computed tomographic scans showed bilateral ground glass opacity (GGO) or GGO with consolidation in the lungs of 27(65.9\%) patients. 31(75.6\%) patients had an abnormal electrocardiograph (ECG). Comparing the three groups, the levels of CRP and cardiac troponin I, GGO distribution in bilateral lungs, and electrocardiogram changes were statistically significant $(p<0.05)$. Cardiac troponin I had a strong positive correlation with CRP $(r=0.704, p=0.042)$ and LDH $(r=0.738, p=0.037)$.

Conclusion: Significant differences among the groups suggest that several clinical parameters may serve as biomarkers of COVID-19 severity at hospital admission. Elevated cTnl could be considered as a predictor of severe COVID-19, reflecting the prognosis of patients with severe COVID-19. The results warrant further inspection and confirmation.
\end{abstract}

Keywords: COVID-19, Clinical characteristics, ACE2, Jilin, CTnI

\footnotetext{
* Correspondence: baowanguo630904@aliyun.com; idadu1980@163.com

${ }^{\dagger}$ Qing Zhang and Qian Xu contributed equally to this work.

'Infectious Diseases Department, First Hospital of Jilin University, Changchun 130021, Jilin, China

Full list of author information is available at the end of the article
}

(C) The Author(s). 2020 Open Access This article is licensed under a Creative Commons Attribution 4.0 International License, which permits use, sharing, adaptation, distribution and reproduction in any medium or format, as long as you give appropriate credit to the original author(s) and the source, provide a link to the Creative Commons licence, and indicate if changes were made. The images or other third party material in this article are included in the article's Creative Commons licence, unless indicated otherwise in a credit line to the material. If material is not included in the article's Creative Commons licence and your intended use is not permitted by statutory regulation or exceeds the permitted use, you will need to obtain permission directly from the copyright holder. To view a copy of this licence, visit http://creativecommons.org/licenses/by/4.0/. The Creative Commons Public Domain Dedication waiver (http://creativecommons.org/publicdomain/zero/1.0/) applies to the data made available in this article, unless otherwise stated in a credit line to the data. 


\section{Introduction}

Beginning in December 2019, a series of unexplained cases of viral pneumonia occurred in Wuhan City, Hubei province. During the following 2 months, the disease broke out in other part of China and internationally as well [1-4]. It was a major public health emergency in China, with the fastest spread, over a wider geographic range, and the most difficult to control, since the founding of New China.

The Coronavirus Research Group of the International Virus Classification Committee changed the name of the causative virus 2019-nCoV to severe acute respiratory syndrome coronavirus 2 (SARS-CoV-2), which was subsequently named by the $\mathrm{WHO}$ as coronavirus disease 2019 (COVID-19).

Coronaviruses include SARS-CoV (severe acute respiratory syndrome coronavirus) and MERS-CoV (Middle East respiratory syndrome coronavirus). SARS-CoV2 is the seventh identified species of human coronavirus, and is most similar to SARS-CoV (77.2\% nucleotide similarity) [2, 5-11]. SARS-CoV-2 infections in humans, with person-to-person transmission, probably began at a seafood market in Wuhan $[2,3,5-8,12,13]$. Wang et al. [8] mentioned that common symptoms include fever, fatigue and dry cough. Low lymphocyte count and elevated LDH in the laboratory and bilateral lungs with GGO in lung CT are the typical features in Wuhan.

Herein, we report early clinical, laboratory, and radiologic features of 41 patients with confirmed diagnosis of SARS-CoV-2 infection in Changchun, Jilin Province. The clinical features of patients with mild, moderate, and severe disease were compared [14].

\section{Methods}

This retrospective study was approved by the Ethics Committee of First Hospital of Jilin University and Infectious Diseases Hospital in Changchun City, Jilin Province (No.2020-399). The need to obtain informed consent from the patients was waived.

\section{Patients}

The local government of Changchun City, Jilin Province mandated the treatment of patients infected with COVID19 to First Hospital of Jilin University and Infectious Disease Hospital. This study enrolled all patients with COVID-19 who were admitted to these hospitals from 23 January 2020 to 25 February 2020. The diagnoses of COVID-19, inclusion and exclusion criteria, and criteria for hospital admission were in accordance with the guidelines of the National Health Commission of China.

\section{Data collection}

The clinical information, laboratory results, and chest computed tomography (CT) features of all the patients were collected from the electronic medical network of the hospitals. To ensure accuracy of the data, two independent researchers reviewed and checked the data forms.

\section{Stratification of patients by severity of disease}

All patients were classified as having mild (ie, nonpneumonia), moderate (ie, pneumonia), or severe disease (ie, dyspnea, respiratory frequency $30 / \mathrm{min}$, blood oxygen saturation 93\%, partial pressure of arterial oxygen to fraction of inspired oxygen ratio $50 \%$ within 24 to $48 \mathrm{~h}$ ), based on the novel Coronavirus-Infected Pneumonia Diagnosis and Treatment Plan (Trial Version 7) announced by the National Health and Medical Commission of China [14].

\section{Statistical analysis}

Continuous variables are reported as means and standard deviations or medians and interquartile ranges. Categorical variables are shown as number and percentage, and comparisons of the mild, the moderate, and severe groups were performed with the Fisher's exact test. When comparing multiple groups, the Kruskal-Wallis $\mathrm{H}$ test is required for continuous variables. After the test, a pairwise comparison is required. In order to make the calculation result more accurate and reduce Type I errors, Bonferroni correction must be performed. And the correlation coefficient was derived Pearson's correlation analysis. Statistical analyses were performed using SPSS software (version 22.0). A $P$ value $<0.05$ by Fisher's Exact test and a $p$ value $<0.0167$ by Kruskal-Wallis $\mathrm{H}$ test were considered statistically significant. All probabilities are two-tailed.

\section{Results \\ Clinical data}

A total of 41 diagnosed COVID-19 cases were enrolled in this study. The overall median age of the 41 patients was 45 years (interquartile range, $31-53$; range, $10-87$ y) (Table 1, Fig. 1). The age of the 3 groups was not significantly different (Table 2). The groups with mild, moderate, or severe disease comprised 5, 28, and 8 patients, respectively. No patients entered the Intensive Care Unit, and none died. None had HBV/HCV infection. There were only one child in the mild disease group and no adolescent patients in the overall study population. The gender ratio of the 3 groups was not significantly different (Table 2). 32(78\%) of the patients had received oxygen therapy (Table 1). Only 4 patients among the 3 groups (9.8\%) had visited Wuhan. All of these patients were in the severe group and had received oxygen therapy, Overall, the oxygen therapy of the 3 groups was not significantly different (Table 2). 
Table 1 Demographics and clinical signs at hospital admission in patients overall ${ }^{\mathrm{a}}$

\begin{tabular}{|c|c|c|}
\hline Variables & $N=41$ & \\
\hline Female, (\%) & $18(43.9)$ & \\
\hline Age,(years) & $45(31,53)$ & \\
\hline Temperature, $\left({ }^{\circ} \mathrm{C}\right)$ & $\begin{array}{l}37.2(36.6 \\
38.0)\end{array}$ & \\
\hline Oxygen saturation, (\%) & $97(95,99)$ & \\
\hline \multicolumn{3}{|l|}{ Travel/Contact history, (\%) } \\
\hline Wuhan & $4(9.8)$ & \\
\hline Wuhan-related & $28(68.3)$ & \\
\hline Beijing & $4(9.8)$ & \\
\hline Thailand & $5(12.2)$ & \\
\hline \multicolumn{3}{|l|}{ Underlying Diseases } \\
\hline Hypertension, (\%) & $7(17.1)$ & \\
\hline Diabetes, (\%) & $3(7.3)$ & \\
\hline COPD, (\%) & $2(4.9)$ & \\
\hline Coronary heart disease, (\%) & $1(2.4)$ & \\
\hline HBV/HCV Infection & 0 & \\
\hline Laboratory results & & $\begin{array}{l}\text { Normal } \\
\text { range }\end{array}$ \\
\hline Lymphocyte percentage, (\%) & $23.91 \pm 9.90$ & $20-40$ \\
\hline Lymphocyte count,(10^9/L) & $1.29 \pm 0.63$ & $1.1-1.32$ \\
\hline $\mathrm{CRP},(\mathrm{mg} / \mathrm{L})$ & $\begin{array}{l}11.3(2.45, \\
35.2)\end{array}$ & $0-6$ \\
\hline $\mathrm{LDH},(\mathrm{U} / \mathrm{L})$ & $\begin{array}{l}226.15 \pm \\
59.67\end{array}$ & $109-245$ \\
\hline $\mathrm{CK},(\mathrm{U} / \mathrm{L})$ & $\begin{array}{l}78.0 \\
(56.5138 .0)\end{array}$ & $26-174$ \\
\hline CK-MB,(U/L) & $\begin{array}{l}17.0(12.0 \\
24.5)\end{array}$ & $0-24$ \\
\hline cTnl,(ng/mL) & $1.5(0.8,5.0)$ & $0-0.5$ \\
\hline Myoglobin,(mg/mL) & $\begin{array}{l}26.0 \\
(19.7118 .6)\end{array}$ & $0-85$ \\
\hline $\mathrm{AST},(\mathrm{U} / \mathrm{L})$ & $\begin{array}{l}26.0(21.0, \\
34.0)\end{array}$ & $8-40$ \\
\hline$A L T,(U / L)$ & $\begin{array}{l}27.0(19.3 \\
46.5)\end{array}$ & $5-40$ \\
\hline WBC, $(10 \wedge 9 / L)$ & $5.42 \pm 1.73$ & $3.5-9.5$ \\
\hline \multicolumn{3}{|l|}{ ECG, $(\%)$} \\
\hline Normal & $9(22)$ & \\
\hline Abnormal & $31(78)$ & \\
\hline \multicolumn{3}{|l|}{ Lung imagings, (\%) } \\
\hline Nonpneumonia & $5(12.2)$ & \\
\hline Pneumonia & $36(87.8)$ & \\
\hline $\begin{array}{l}\text { Bilateral GGO \& Consolidation \&Pleural } \\
\text { effusion } \\
\text { Unilateral GGO \& Consolidation }\end{array}$ & $\begin{array}{l}27(65.8) 9 \\
(22)\end{array}$ & \\
\hline \multicolumn{3}{|l|}{ Group, (\%) } \\
\hline Mild & $5(12.2)$ & \\
\hline
\end{tabular}

Table 1 Demographics and clinical signs at hospital admission in patients overall ${ }^{\mathrm{a}}$ (Continued)

\begin{tabular}{ll}
\hline Variables & $\mathbf{N = 4 1}$ \\
\hline Moderate & $28(68.3)$ \\
Severe & $8(19.5)$ \\
Oxygen Therapy, (\%) & $32(78)$ \\
$\begin{array}{l}\text { The numbers of "day of illness" at } \\
\text { admission,(days) }\end{array}$ & $4.29 \pm 1.4$
\end{tabular}

${ }^{a}$ Reported as means and standard deviations or medians and interquartile ranges for continuous variables, and reported as number and percentage for categorical variables

$A L T$ alanine aminotransferase; $A S T$ aspartate aminotransferase; $C K$ creatine kinase; $C K-M B$ creatine kinase-myocardial band; $C R P$ c-reactive protein; $C T n l$ cardiac troponin-I; $L D H$ lactate dehydrogenase; $W B C$ white blood cell count; ECG electrocardiograph; HBV, hepatitis B Virus; HCV, hepatitis C Virus;COPD, chronic obstructive pulmonary disease

Overall, fever (78\%) and cough (70.7\%) were the most common symptoms at onset (Table 3). Less common symptoms were sputum production $(29.3 \%)$, chest tightness $(29.3 \%)$, shortness of breath (26.8\%), runny nose $(14.6 \%)$, sore throat $(14.6 \%)$, diarrhea $(12.2 \%)$, and nasal congestion (9.8\%). There was no significant difference in clinical symptoms among the three groups $(P>0.05)$.

\section{Routine blood results}

For the overall population, the routine blood tests showed that 18 (43.9\%), 15 (36.6\%), and $6(12.2 \%)$ of the 41 patients had, respectively, low lymphocyte count, low lymphocyte percentage, and low white blood cell (WBC) count (Table 4). We found that the low lymphocyte count and low white blood cell (WBC) count were not statistically significant among the three groups by the Kruskal-Wallis $\mathrm{H}$ test and Bonferroni correction $(p>$ 0.0167) (Table 5).

CRP was elevated in 22 of the 41 patients (Table 4). Specifically, the CRP was normal for all patients in the mild group. CRP was elevated in $14(50 \%)$ of the patients in the moderate group, and elevated in all (100\%) patients of the severe group. The median CRP was $2.10 \mathrm{mg} / \mathrm{L}$ (interquartile range, $1.45-6.45 \mathrm{mg} / \mathrm{L}$ ) of the mild, $7 \mathrm{mg} / \mathrm{L}$ (interquartile range, $2.58-31.9 \mathrm{mg} / \mathrm{L}$ ) in the moderate, and $52.45 \mathrm{mg} / \mathrm{L}$ (interquartile range, $20.53-81.78 \mathrm{mg} / \mathrm{L}$ ) in the severe (Table 5). The patients with high CRP in the severe group was significantly greater than that of the mild and moderate groups $(P=0.003)$.

Within the myocardial enzyme spectrum, cardiac troponin-I (cTnI) was elevated in all patients (Table 4). And we found that the patients in the severe group with elevated cTnI was statistical significantly higher than that of the mild and moderate groups (Table 5) $(P=0.007)$. Interstingly, we used speculated factors such as cTnI and ALT performing Pearson's correlation analysis with LDH and CRP. The results showed that $\mathrm{CTnI}$ had a positive correlation with 


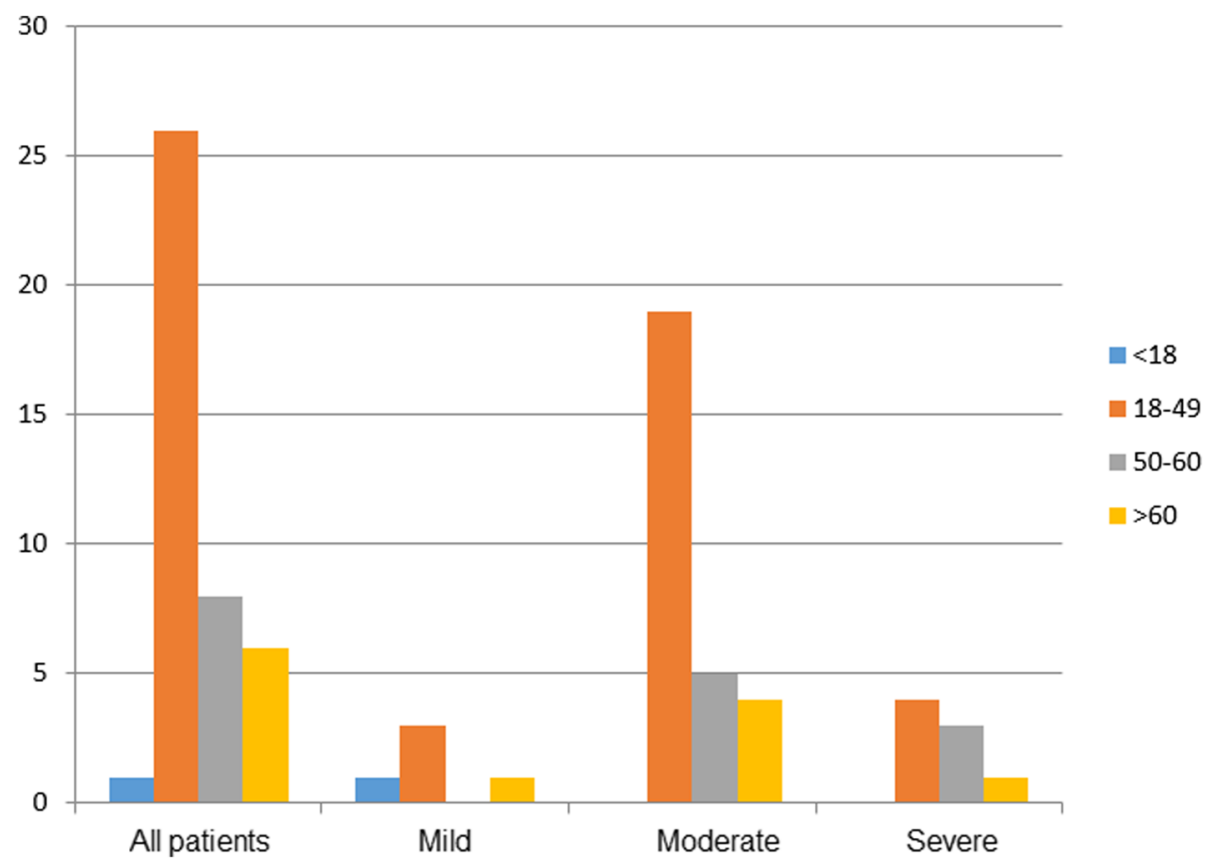

Fig. 1 The age distribution of 41 patients diagnosed with COVID-19 by age group and the age distribution in each group

LDH $(\mathrm{r}=0.738, p=0.037)$ and CRP $(\mathrm{r}=0.74, p=$ 0.042). And there was no correlation between ALT and CRP $(p>0.05)$ (Table 6). And the elevated AST and ALT had no statistical difference among three groups $(p=0.384$ and $p=0.858)$.

\section{Electrocardiograph and imaging findings}

Among the 41 patients overall, 32(78\%) were abnormal in electrocardiograph (ECG) (Table 7). In the three groups, the changes in ECG were statistically significant $(p=0.002) .5(12.2 \%)$ were nonpneumonia and $27(65.8 \%)$

Table 2 Demographics of patients with COVID-19 at hospital admission in overall population and by disease severity ${ }^{a}$

\begin{tabular}{|c|c|c|c|c|}
\hline Variables & $\operatorname{Mild}(n=5)$ & $\operatorname{Moderate}(n=28)$ & Severe $(n=8)$ & $P$ value \\
\hline Gender, (\%) & & & & 0.632 \\
\hline Male & $4(80)$ & $15(53.6)$ & $4(50)$ & \\
\hline Female & $1(20)$ & $13(46.3)$ & $4(50)$ & \\
\hline Age,(years) & $29(25,80)$ & $45.5(10,79)$ & $47(21,87)$ & 0.564 \\
\hline Temperature, $\left({ }^{\circ} \mathrm{C}\right)$ & $37.5 \pm 0.47$ & $37.3 \pm 1.03$ & $37.3 \pm 1.04$ & 0.954 \\
\hline Oxygen saturation, (\%) & $97(96.5,98)$ & $96(92.5,98.8)$ & $98.5(95.3,99)$ & 0.403 \\
\hline Travel/Contact history, (\%) & $5(100)$ & $25(89.3)$ & $7(87.5)$ & 1 \\
\hline \multicolumn{5}{|l|}{ Underlying } \\
\hline Diseases & 0 & $5(17.9)$ & $2(25)$ & 0.564 \\
\hline Hypertension, (\%) & 0 & $1(0.4)$ & $2(25)$ & 0.127 \\
\hline 1Diabetes, (\%) & $1(20)$ & $1(0.4)$ & 0 & 0.266 \\
\hline $\begin{array}{l}\text { COPD, (\%) } \\
\text { Coronary heart disease, (\%) }\end{array}$ & 0 & 0 & 0 & \\
\hline HBV/HCV Infection & 0 & 0 & 0 & \\
\hline The numbers of "day of illness" at admission,(days) & $4 \pm 1.3$ & $4.5 \pm 1$ & $4.2 \pm 1.1$ & 0.671 \\
\hline Oxygen Therapy,(\%) & $3(60)$ & $21(75)$ & $8(100)$ & 0.201 \\
\hline
\end{tabular}

${ }^{a}$ Reported as means and standard deviations or medians and interquartile ranges for continuous variables, and reported as number and percentage for categorical variables. $P$ values across the mild, moderate, and severe disease groups were derived by Fisher's exact test $H B V$ hepatitis B Virus; HCV hepatitis C Virus; COPD chronic obstructive pulmonary disease 
Table 3 Cardinal symptoms of patients with COVID-19 at hospital admission in overall population and by disease severity ${ }^{a}$

\begin{tabular}{llllll}
\hline & Patients & Mild & Moderate & Severe & P \\
\hline Subjects, $n$ & 41 & 5 & 28 & 8 & - \\
Fever & $32(78)$ & $2(40)$ & $22(78.6)$ & $8(100)$ & 0.123 \\
Cough & $29(70.7)$ & $2(40)$ & $19(67.9)$ & $8(100)$ & 0.058 \\
Sputum production & $9(29.3)$ & 0 & $6(21.4)$ & $3(37.5)$ & 0.281 \\
Chest tightness & $9(29.3)$ & $1(20)$ & $6(21.4)$ & $3(37.5)$ & 0.628 \\
Shortness of breath & $8(26.8)$ & 0 & $5(17.9)$ & $3(37.5)$ & 0.233 \\
Headache & $4(12.2)$ & 0 & $4(14.3)$ & 0 & 0.357 \\
Runny nose & $6(14.6)$ & $1(20)$ & $4(14.3)$ & $1(12.5)$ & 0.929 \\
Diarrhea & $5(12.2)$ & 0 & $5(17.9)$ & 0 & 0.358 \\
Sore throat & $6(14.6)$ & $1(20)$ & $3(10.7)$ & $2(25)$ & 0.245 \\
Nausea & $2(4.9)$ & 0 & $2(7.1)$ & 0 & 0.614 \\
Fatigue & $3(7.3)$ & 0 & $3(10.7)$ & 0 & 0.472 \\
Stuffy nose & $3(7.3)$ & $1(20)$ & $2(7.1)$ & 0 & 0.403 \\
Body pain & $2(4.9)$ & 0 & $2(7.1)$ & 0 & 0.614 \\
Joint pain & $1(2.4)$ & 0 & $1(3.6)$ & 0 & 0.789 \\
\hline
\end{tabular}

${ }^{a}$ Reported as $\mathrm{n}(\%)$, unless indicated otherwise. $\mathrm{P}$ values across the mild, moderate, and severe disease groups were derived by Fisher's exact test had bilateral distributed pneumonia (Table 8). Twenty-six patients (63.4\% Fig. 2) had ground-glass opacity (GGO) shadows or had GGO combined with solid shadows (consolidation with GGO) or pleural effusion (Fig. 3). All patients in the mild group were normal on CT scan. In the moderate group, 18 patients had GGO or GGO with consolidation. (64.3\%; Fig. 2). In the severe group, lesions were bilateral in all (100\%) of the patients, and $8(100 \%)$ had GGO or GGO with consolidation (Fig. 3). Bilateral lung distribution and GGO or GGO with consolidation were meaningful in the three groups $(P>0.05)$.

\section{Discussion}

This report describes the clinical characteristics of 41 patients with diagnosed COVID-19 in Changchun, Jilin Province. All the patients had a history of Wuhanrelated exposure or travel. And eight of them had familial cluster disease. The median age of the patients was 45 years (interquartile range, 31, 53; range, 10-87 y). The population was stratified as mild, moderate, and severe disease based on the COVID-19 Diagnosis and

Table 4 Blood routine results of patients with COVID-19 at hospital admission in overall population and by disease severity ${ }^{a}$

\begin{tabular}{|c|c|c|c|c|c|c|}
\hline & & Patients & Mild & Moderate & Severe & $\mathbf{P}$ \\
\hline Subjects, n & & 41 & 5 & 28 & 8 & - \\
\hline \multirow[t]{2}{*}{ WBC $\left(3.5-9.5 \times 10^{9} / L\right)$} & Normal & $36(87.8)$ & $5(100)$ & $26(92.9)$ & $5(62.5)$ & 0.046 \\
\hline & Low & $5(12.2)$ & 0 & $2(7.1)$ & $3(37.5)$ & \\
\hline \multirow[t]{2}{*}{ Lymphocyte percentage (20-40\%) } & Normal & $26(63.4)$ & $3(60)$ & $18(64.3)$ & $5(62.5)$ & 0.398 \\
\hline & Low & $15(36.6)$ & $2(40)$ & $10(35.7)$ & $3(37.5)$ & \\
\hline \multirow[t]{2}{*}{ Lymphocyte count $\left(1.1-3.2 \times 10^{9} / \mathrm{L}\right)$} & Normal & $23(56.1)$ & $5(100)$ & $17(60.7)$ & $1(12.5)$ & 0.006 \\
\hline & Low & $18(43.9)$ & 0 & $11(39.3)$ & $7(87.5)$ & \\
\hline \multirow[t]{2}{*}{ CRP (0-6 mg/L) } & Normal & $19(46.3)$ & $5(100)$ & $14(50)$ & 0 & 0.002 \\
\hline & Elevated & $22(53.7)$ & 0 & $14(0)$ & $8(100)$ & \\
\hline \multirow[t]{2}{*}{ LDH (109-24 U/L) } & Normal & $32(78)$ & $5(100)$ & $24(87.5)$ & $3(62.5)$ & 0.007 \\
\hline & Elevated & $9(22)$ & 0 & $4(14.3)$ & $5(62.5)$ & \\
\hline \multirow[t]{2}{*}{ CK (26-174 U/L) } & Normal & $35(85.4)$ & $5(100)$ & $25(89.3)$ & $5(62.5)$ & 0.103 \\
\hline & Elevated & $6(14.6)$ & 0 & $3(10.7)$ & $3(37.5)$ & \\
\hline \multirow[t]{2}{*}{ CK-MB (0-24 U/L) } & Normal & $33(80.5)$ & $4(80)$ & $23(82.1)$ & $6(75)$ & 0.903 \\
\hline & Elevated & $8(19.5)$ & $1(20)$ & $5(17.9)$ & $2(25)$ & \\
\hline \multirow[t]{2}{*}{ CTnl (0-0.5 ng/mL) } & Normal & 0 & 0 & 0 & 0 & 0.621 \\
\hline & Elevated & $41(100)$ & $5(100)$ & $28(100)$ & $8(100)$ & \\
\hline \multirow[t]{2}{*}{ Myoglobin (0-85 mg/mL) } & Normal & $30(73.2)$ & $5(100)$ & $23(82.1)$ & $2(25)$ & 0.002 \\
\hline & Elevated & $11(26.8)$ & 0 & $5(17.9)$ & $6(75)$ & \\
\hline \multirow[t]{2}{*}{ AST (8-40 U/L) } & Normal & 35 (85.4) & $5(100)$ & $23(82.1)$ & 7 (87.5) & 0.571 \\
\hline & Elevated & $6(14.6)$ & 0 & $5(17.9)$ & $1(12.5)$ & \\
\hline \multirow[t]{2}{*}{$\operatorname{ALT}(5-40 \mathrm{U} / \mathrm{L})$} & Normal & $27(65.9)$ & $5(100)$ & 19 (67.9) & $3(37.5)$ & 0.064 \\
\hline & Elevated & $14(34.1)$ & & $9(32.1)$ & $5(62.5)$ & \\
\hline
\end{tabular}

${ }^{a}$ Reported as $\mathrm{n}(\%)$, unless indicated otherwise. $\mathrm{P}$ values across the mild, moderate, and severe disease groups were derived by Fisher's exact test. All blood routine results were obtained upon admission

$A L T$ alanine aminotransferase; $A S T$ aspartate aminotransferase; $C K$ creatine kinase; $C K-M B$ creatine kinase-myocardial band; $C R P$ c-reactive protein; $C T n /$ cardiac troponin-I; $L D H$ lactate dehydrogenase; WBC white blood cell count 
Table 5 Blood routine results of patients with COVID-19 at hospital admission by disease severity ${ }^{\mathrm{a}}$

\begin{tabular}{llllll}
\hline Variables & Normal range & Mild $(\boldsymbol{n}=\mathbf{5})$ & Moderate $(\boldsymbol{n}=\mathbf{2 8})$ & Severe $(\boldsymbol{n}=\mathbf{8})$ & P value \\
\hline WBC,(10^9/L) & $3.5-9.5$ & $6.46(4.18,7.86)$ & $5.56(4.85,6.55)$ & $4.60(2.97,5.03)$ & 0.063 \\
Lymphocyte percentage, (\%) & $20-40$ & $23.6(18.1,44.5)$ & $21.8(14.6,28.9)$ & $24.4(14.7,28.7)$ & 0.670 \\
Lymphocyte count, (10^9/L) & $1.1-3.2$ & $2.15(1.14,2.43)$ & $1.20(0.81,1.65)$ & $0.91(0.65,1.18)$ & 0.052 \\
CRP,(mg/L) & $0-6$ & $2.10(1.45,6.45)$ & $7.00(2.58,31.90)$ & $52.45(20.53,81.78)$ & 0.003 \\
LDH,(U/L) & $109-245$ & $210.0(182.5283 .0)$ & $205.5(181.3244 .3)$ & $258.5(209.5311 .0)$ & 0.184 \\
CK,(U/L) & $26-174$ & $114.0(63.0,135.0)$ & $75.0(58.0,123.8)$ & $113.0(49.3249 .8)$ & 0.866 \\
CK-MB,(U/L) & $0-24$ & $20.0(16.0,64.0)$ & $15.0(11.0,20.0)$ & $20.5(12.0,56.5)$ \\
CTnl,(ng/mL) & $0-0.5$ & $1.20(0.75,1.75)$ & $1.30(0.65,1.90)$ & $9.05(1.95,10.83)$ \\
myoglobin,(mg/mL) & $0-85$ & $22.8(19.1,25.9)$ & $26.0(21.3,32.2)$ & $141.6(19.4171 .3)$ & 0.133 \\
AST,(U/L) & $8-40$ & $28.0(23.5,30.0)$ & $25.0(20.0,32.0)$ & $31.5(24.3,39.0)$ & 0.007 \\
ALT,(U/L) & $5-40$ & $24.0(15.0,45.0)$ & $29.0(19.0,49.0)$ & $26.5(20.0,47.5)$ & 0.384 \\
\hline
\end{tabular}

${ }^{a}$ Reported as median, and interquartile range (IQR) values. $\mathrm{P}$ values across the mild, moderate, and severe disease groups were derived by Kruskal-Wallis $\mathrm{H}$ test and Bonferroni correction. All blood routine results were obtained upon admission

ALT alanine aminotransferase; AST aspartate aminotransferase; CK creatine kinase; CK-MB creatine kinase-myocardial band; CRP C-reactive protein; CTnl cardiac troponin-l; $L D H$ lactate dehydrogenase; WBC white blood cell count

Treatment Plan (Trial Version 7) announced by the National Health and Medical Commission of China [14]. Four of the patients came to Jilin after visiting Wuhan, and all of them had severe disease and required oxygen therapy, with blood oxygen saturation less than $93 \%$. This cutoff is a guide for treating patients outside $\mathrm{Wu}-$ han. As it was important for patients with COVID-19 to have oxygen therapy, 32(78\%) had oxygen therapy, which was consistent with other studies [15].

In this population, the majority of the patients (28, $68.3 \%$ ) had moderate disease. As of 25 January, there were no adolescents among our first 41 patients, and only $1(2.4 \%)$ child. This is consistent with other research [1]. The common history of these patients of close contact or travel is also consistent with other studies [16]. The main clinical symptoms overall and in each group were fever and cough. Few presented with significant upper respiratory signs and symptoms (e.g., nasal congestion, sneezing, or sore throat).

The pathogenic mechanism of COVID-19 has not been fully elucidated. Coronary viral receptor cells may be located in the lower respiratory tract $[1,16]$. Based on the similarity of SARS-CoV-2 with SARS-CoV, it has been the fact that these viruses share the same receptor, angiotensin-converting enzyme 2 (ACE2). SARS-CoV-2 enters cells by binding to the receptor ACE2 driven by $\mathrm{S}$ protein; and its affinity is 10 - to 20 -fold that of SARS$\mathrm{CoV}$. This indicates that ACE2 has a vital role in the viral invasion of cells. Indeed, all cells that can secrete ACE2 may become target cells and are more susceptible to SARS-CoV-2 infection [17-19]. ACE2 is distributed in the heart, lung, gastrointestinal tract, and liver. Some studies have suggested that SARS-CoV-2 attack cells that secrete ACE2 in alveolar epithelial cells. This interferes with the balance of the ACE2/Ang- [1-7]/Mas axis, which leads to a series of inflammatory reactions and then respiratory discomfort such as fever, cough, and sputum production $[20,21]$. Similarly, there are reports that the gastrointestinal discomfort such as nausea and diarrhea experienced by patients with moderate disease may be related to an abundance of ACE2 in digestive tract cells [22, 23].

Table 6 The ECG results of patients with COVID-19 at hospital admission by disease severity ${ }^{\text {a }}$

\begin{tabular}{|c|c|c|c|c|}
\hline Variable & Mild $(n=5)$ & Moderate $(n=28)$ & Severe $(n=8)$ & $P$ value \\
\hline ECG, (\%) & & & & 0.002 \\
\hline Normal & $1(20)$ & $8(28.6)$ & 0 & \\
\hline Changes of ST-T or VPC & $4(80)$ & $11(39.3)$ & 0 & \\
\hline Flatness and inversion of T waves or Left anterior branch block & 0 & $6(21.4)$ & $3(37.5)$ & \\
\hline QS waves in $I, I I I$ and avF leads & 0 & $3(10.7)$ & $5(62.5)$ & \\
\hline
\end{tabular}

${ }^{a}$ Reported as $\mathrm{n}(\%)$, unless indicated otherwise. $\mathrm{P}$ values across the mild, moderate, and severe disease groups were derived by Fisher's exact Test ECG electrocardiograph

VPC ventricular premature contraction 
Table 7 Lung CT results of patients with COVID-19 at hospital admission in overall population and by disease severity ${ }^{a}$

\begin{tabular}{|c|c|c|c|c|}
\hline Subjects, $n$ & Mild(n=5) & Moderate $(n=28)$ & Severe $(n=8)$ & $P$ value \\
\hline Distribution & & & & $<0.001$ \\
\hline Nonpneumonia & $5(100)$ & 0 & 0 & \\
\hline Bilateral & 0 & $19(67.9)$ & $8(100)$ & \\
\hline Unilateral & 0 & $9(32.1)$ & 0 & \\
\hline Characteristics & & & & 0.001 \\
\hline No GGO & $5(100)$ & $10(35.7)$ & 0 & \\
\hline Consolidation \& GGO \& Pleural effusion & 0 & $18(64.3)$ & $8(100)$ & \\
\hline
\end{tabular}

a Reported as $\mathrm{n}(\%)$, unless indicated otherwise. $\mathrm{P}$ values across the mild, moderate, and severe disease groups were derived by Fisher's exact test GGO ground-glass opacity

In this study, although there were low lymphocyte counts and high LDH changes, they were not statistically significant in the three groups. This was contrary to other studies [24-28]. Due to the limited number of samples, further studies were needed to confirm the results. The elevated CRP was related to disease severity, which was in line with other studies [26-29].

In the present study, no abnormal changes were noted in the lung CT scans of the patients with mild disease. For patients in the moderate and severe groups, the most common CT features were GGO and GGO combined with consolidation. The differences were significant among the 3 groups $(P<0.001)$, which were consistent with other studies $[1,7,16]$.

In our study, it was found that the elevation of cardiac troponin I (cTnI) and the changes of ECG were statistically significant in the three groups. Related literature [30-32] reported that the elevated troponin of COVID-

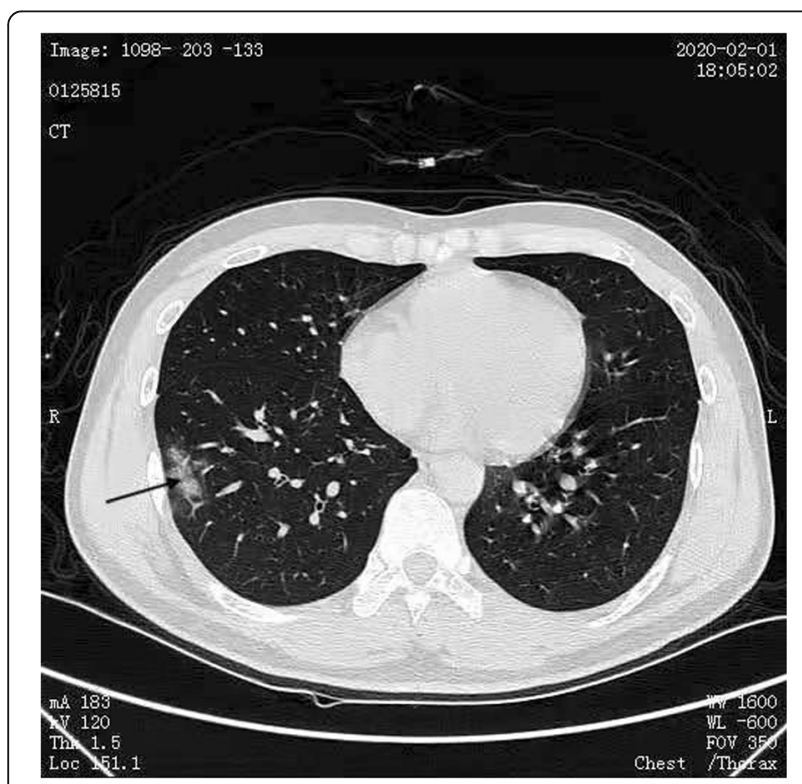

Fig. 2 A flaky GGO was observed under the right lung pleura (black arrow)
19 patients who died was much higher than that of survivors and that cardiac troponin I was directly related to mortality. Also it was proposed that the increase in troponin may be related to heart damage or myocarditis caused by COVID-19. The related document [33] has studied that the sensitivity of myocardial cells to SARS$\mathrm{CoV}-2$ is one of the mechanisms of myocardial injury, and other mechanisms have also been studied in other relevant literatures [32, 34-36]. So far the specific mechanism of the heart damage and elevated cTnI remains unknown. According to the upper limit of troponin I [TnI] elevation greater than $99 \%$, it is defined as heart injury. Combining the elevation of cTnI and the changes in electrocardiogram (ECG) in this study, the existence of cardiac injury is considered, which is consistent with other studies [30-32, 34-36].

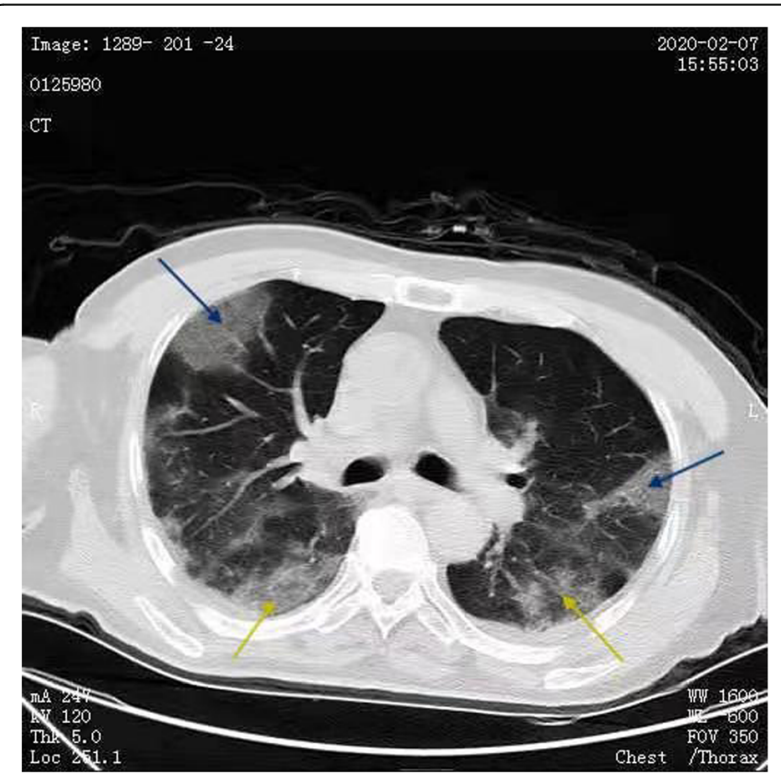

Fig. 3 Multiple areas of patchy GGO and solid shadow (blue arrow) were seen under the pleura of both lungs with bilateral pleural effusion (yellow arrow) 
Table 8 Correlation with LDH and CRP in severe group ${ }^{a}$

\begin{tabular}{|c|c|c|c|c|}
\hline \multirow{2}{*}{$\begin{array}{l}\text { Predictive } \\
\text { factors }\end{array}$} & \multicolumn{2}{|l|}{$\mathrm{LDH}(\mathrm{U} / \mathrm{L})$} & \multicolumn{2}{|l|}{ CRP (mg/L) } \\
\hline & Correlation coefficient & $P$ value & Correlation coefficient & $P$ value \\
\hline $\mathrm{cTnl}(\mathrm{ng} / \mathrm{mL})$ & 0.738 & 0.037 & 0.704 & 0.035 \\
\hline $\mathrm{ALT}(\mathrm{U} / \mathrm{L})$ & 0.321 & 0.678 & 0.397 & 0.331 \\
\hline
\end{tabular}

${ }^{a}$ The correlation coefficient and $\mathrm{p}$ value across the severe were derived by Pearson's correlation analysis CRP C-reactive protein; $L D H$ lactate dehydrogenase; $C T n /$ cardiac troponin-l; ALT alanine aminotransferase

In order to further clarify whether elevated troponin could also be used as a predictor for early identification of severe COVID-19, we used Pearson's correlation analysis to analyze the correlation between cardiac troponin I (cTnI) and CRP and LDH. Interestingly, We found that cTnI was strongly positively correlated with CRP $(\mathrm{r}=0.704, p=0.042)$ and $\mathrm{LDH}(\mathrm{r}=0.738, p=0.037)$, and related literature [26-29] had reported that both LDH and CRP can be used as powerful predictors for early identification of patients with severe COVID-19. Therefore, elevated cTnI could be considered as a candidate predictor of severe COVID-19, reflecting the prognosis of patients with severe COVID-19.

\section{Conclusion}

In this study, the clinical characteristics of 41 confirmed COVID-19 patients in Jilin Province were retrospectively analyzed. Elevated cTnI could be considered as a predictor of severe COVID-19, reflecting the prognosis of patients with severe COVID-19. The result warrant further confirmation. As of this writing, there is no effective medicine for the treatment of COVID-19. This study may provide guidance for the treatment of patients based on clinical characteristics, a scientific basis for the screening of patients, and references for future research.

\section{Abbreviations \\ GGO: Ground-glass opacity; WHO: World Health Organization; SARS-CoV- 2: Severe acute respiratory syndrome coronavirus 2; CT: Computed tomography; WBC: White blood cell; CTnl: cardiac troponin-l; CK: Creatine kinase; CK: Myocardial band or CK-MB; LDH: Lactate dehydrogenase; ALT: Alanine aminotransferase; AST: Aspartate aminotransferase; ACE2: Angiotensin-converting enzyme 2; CRP: C-reactive protein; ECG: Electrocardiograph; HBV: Hepatitis B Virus; HCV: Hepatitis C Virus; VPC: Ventricular premature contraction}

\section{Acknowledgements}

We thank Medjaden Bioscience Limited for scientific editing of this manuscript.

\section{Authors' contributions}

QZ designed/performed most of the investigation, data analysis and wrote the manuscript; QX provided the acquisition of the data and took part in writing the manuscript; ND provided the major thesis supervision and have made substantial contributions to the conception OR design of the work; WGB provided the thesis supervision, financial support, and have drafted the work; YYC provided the acquisition of the data and interpretation of data; LXL provided the collection and analysis of data; LHC took part in the substantively revision of the manuscript; XHL contributed to the collection of data and the creation of new software used in the work; and LYS modified the format of the manuscript and the creation of new software used in the work. All of the authors have read and approved the manuscript.

\section{Funding}

Not applicable.

\section{Availability of data and materials}

The datasets generated and analyzed during the present study are available from the corresponding author on reasonable request.

\section{Ethics approval and consent to participate}

The written informed consent could not be obtained from all people during the epidemic, which has been approved by the ethics committee because of the epidemic, and the verbal informed consent has been obtained from all people at the time of admission. This study was approved by the ethics committee of the First Hospital of Jilin University and the Infectious Diseases Hospital of Changchun City (No.2020-399). All procedures performed in studies involving human participants were in accordance with the ethical standards of the institutional and/or national research committee and with the 1964 Helsinki declaration and its later amendments or comparable ethical standards. All the data used in this study was anonymised before its use.

\section{Consent for publication}

Not applicable.

\section{Competing interests}

All authors declare that there are no conflicts.

\section{Author details}

${ }^{1}$ Infectious Diseases Department, First Hospital of Jilin University, Changchun 130021, Jilin, China. ${ }^{2}$ Integrated Chinese and Western Medicine Department, the Infectious Diseases Hospital of Changchun City, Changchun 130123, Jilin, China.

Received: 13 April 2020 Accepted: 30 November 2020 Published online: 17 December 2020

References

1. Huang C, Wang Y, Li X, Ren L, Zhao J, Hu Y, et al. Clinical features of patients infected with 2019 novel coronavirus in Wuhan, China. Lancet. 2020;395(10223):497-506.

2. Chan JF, Yuan S, Kok KH, To KK, Chu H, Yang J, et al. A familial cluster of pneumonia associated with the 2019 novel coronavirus indicating personto-person transmission: a study of a family cluster. Lancet. 2020;395(10223): 514-23.

3. Chen N, Zhou M, Dong X, Qu J, Gong F, Han Y, et al. Epidemiological and clinical characteristics of 99 cases of 2019 novel coronavirus pneumonia in Wuhan, China: a descriptive study. Lancet. 2020;395(10223):507-13.

4. Zhu N, Zhang D, Wang W, Li X, Yang B, Song J, et al. A novel coronavirus from patients with pneumonia in China, 2019. N Engl J Med. 2020;382(8): 727-33.

5. Tang Q, Song $Y$, Shi M, Cheng $Y$, Zhang W, Xia XQ. Inferring the hosts of coronavirus using dual statistical models based on nucleotide composition. Sci Rep. 2015:5:17155.

6. Phan LT, Nguyen TV, Luong QC, Nguyen TV, Nguyen HT, Le HQ, et al. Importation and human-to-human transmission of a novel coronavirus in Vietnam. N Engl J Med. 2020;382(9):872-4.

7. Lupia T, Scabini S, Mornese Pinna S, Di Perri G, De Rosa FG, Corcione S. 2019 novel coronavirus (2019-nCoV) outbreak: a new challenge. J Glob Antimicrob Resist. 2020;21:22-7. 
8. Wang D, Hu B, Hu C, Zhu F, Liu X, Zhang J, et al. Clinical Characteristics of 138 Hospitalized Patients With 2019 Novel Coronavirus-Infected Pneumonia in Wuhan, China. JAMA. 2020;323(11):1061-9.

9. Ren $L L$, Wang $Y M, W u Z Q$, Xiang ZC, Guo L, Xu T, et al. Identification of a novel coronavirus causing severe pneumonia in human: a descriptive study. Chin Med J (Engl). 2020;133(9):1015-24.

10. Wu F, Zhao S, Yu B, Chen YM, Wang W, Song ZG, et al. A new coronavirus associated with human respiratory disease in China. Nature. 2020;579(7798): 265-9.

11. Yu F, Du L, Ojcius DM, Pan C, Jiang S. Measures for diagnosing and treating infections by a novel coronavirus responsible for a pneumonia outbreak originating in Wuhan, China. Microbes Infect. 2020;22(2):74-9.

12. Carlos WG, Dela Cruz CS, Cao B, Pasnick S, Jamil S. Novel Wuhan (2019nCoV) coronavirus. Am J Respir Crit Care Med. 2020;201(4):P7-p8.

13. Gorbalenya AE, Snijder EJ, Spaan WJ. Severe acute respiratory syndrome coronavirus phylogeny: toward consensus. J Virol. 2004;78(15):7863-6.

14. Diagnosis and treatment of new coronavirus pneumonia (trial version 7) [J / OL]. Tianjin J Tradit Chin Med. 2020;1-5. http://kns.cnki.net/kcms/ detail/12.1349.R.20200304.1638.006.html. Accessed 3 June 2020.

15. Pan W, Li J, Ou Y, Wu Y, Cai S, Zhang Y, et al. Clinical outcome of standardized oxygen therapy nursing strategy in COVID-19. Ann Palliat Med. 2020;9(4):2171-7.

16. Shi $\mathrm{H}$, Han $\mathrm{X}$, Jiang $\mathrm{N}$, Cao Y, Alwalid O, Gu J, et al. Radiological findings from 81 patients with COVID-19 pneumonia in Wuhan, China: a descriptive study. Lancet Infect Dis. 2020;20(4):425-34.

17. Xu X, Chen P, Wang J, Feng J, Zhou H, Li X, et al. Evolution of the novel coronavirus from the ongoing Wuhan outbreak and modeling of its spike protein for risk of human transmission. Sci China Life Sci. 2020;63(3):457-60.

18. Kuhn JH, Li W, Choe H, Farzan M. Angiotensin-converting enzyme 2: a functional receptor for SARS coronavirus. Cell Mol Life Sci. 2004;61 (21):2738-43.

19. Zou X, Chen K, Zou J, Han P, Hao J, Han Z. Single-cell RNA-seq data analysis on the receptor ACE2 expression reveals the potential risk of different human organs vulnerable to 2019-nCoV infection. Front Med. 2020;14(2):185-92.

20. Xu H, Zhong L, Deng J, Peng J, Dan H, Zeng X, et al. High expression of ACE2 receptor of 2019-nCoV on the epithelial cells of oral mucosa. Int J Oral Sci. 2020;12(1):8.

21. Hamming I, Timens W, Bulthuis ML, Lely AT, Navis G, van Goor H. Tissue distribution of ACE2 protein, the functional receptor for SARS coronavirus. A first step in understanding SARS pathogenesis. J Pathol. 2004;203(2):631-7.

22. Wrapp D, Wang N, Corbett KS, Goldsmith JA, Hsieh CL, Abiona O, et al. Cryo-EM structure of the 2019-nCoV spike in the prefusion conformation. Science. 2020;367(6483):1260-3.

23. Ding Y, He L, Zhang Q, Huang Z, Che X, Hou J, et al. Organ distribution of severe acute respiratory syndrome (SARS) associated coronavirus (SARS-CoV) in SARS patients: implications for pathogenesis and virus transmission pathways. J Pathol. 2004;203(2):622-30.

24. Li T, Qiu Z, Zhang L, Han Y, He W, Liu Z, et al. Significant changes of peripheral T lymphocyte subsets in patients with severe acute respiratory syndrome. J Infect Dis. 2004;189:648-51.

25. Liu J, Zheng X, Tong Q, Li W, Wang B, Sutter K, et al. Overlapping and discrete aspects of the pathology and pathogenesis of the emerging human pathogenic coronaviruses SARS-CoV, MERS-CoV, and 2019-nCoV. J Med Virol. 2020;92:491-4.

26. Poggiali E, Zaino D, Immovilli P, Rovero L, Losi G, Dacrema A, et al. Lactate dehydrogenase and $\mathrm{C}$-reactive protein as predictors of respiratory failure in CoVID-19 patients. Clin Chim Acta. 2020;509:135-8.

27. Han Y, Zhang H, Mu S, Wei W, Jin C, Tong C, et al. Lactate dehydrogenase, an independent risk factor of severe COVID-19 patients: a retrospective and observational study. Aging (Albany NY). 2020;12(12):11245-58.

28. Tan C, Huang Y, Shi F, Tan K, Ma Q, Chen Y, et al. C-reactive protein correlates with computed tomographic findings and predicts severe COVID19 early. J Med Virol. 2020;92(7):856-62.

29. Li Q, Ding X, Xia G, Chen HG, Chen F, Geng Z, et al. Eosinopenia and elevated C-reactive protein facilitate triage of COVID-19 patients in fever clinic: a retrospective case-control study. EClinicalMedicine. 2020;23:100375.

30. Shi S, Qin M, Shen B, Cai YL, Liu T, Yang F, et al. Association of cardiac injury with mortality in hospitalized patients with COVID-19 in Wuhan, China. JAMA Cardiol. 2020;5(7):802-10

31. Guo T, Fan Y, Chen M, Wu XY, Zhang L, He T, et al. Cardiovascular implications of fatal outcomes of patients with coronavirus disease 2019 (COVID-19). JAMA Cardiol. 2020;5(7):811-8.
32. Zhou F, Yu T, Du R, Fan GH, Liu Y, Liu ZB, et al. Clinical course and risk factors for mortality of adult inpatients with COVID-19 in Wuhan, China: a retrospective cohort study. Lancet. 2020;395(10229):1054-62.

33. Sharma A, Garcia G Jr, Wang Y, Plummer JT, Morizono K, Arumugaswami V, et al. Human ipsc-derived cardiomyocytes are susceptible to Sars-Cov-2 infection. Cell Rep Med. 2020;1(4):100052.

34. Long B, Brady WJ, Koyfman A, Gottlieb M. Cardiovascular complications in COVID-19. Am J Emerg Med. 2020;38(7):1504-7.

35. Imazio M, Klingel K, Kindermann I, Brucato A, De Rosa FG, Adler Y, et al. COVID-19 pandemic and troponin: indirect myocardial injury, myocardial inflammation or myocarditis? Heart. 2020;106(15):1127-31.

36. Varga Z, Flammer AJ, Steiger P, Haberecker M, Andermatt R, Zinkernagel AS, et al. Endothelial cell infection and endotheliitis in COVID-19. Lancet. 2020; 395(10234):1417-8.

\section{Publisher's Note}

Springer Nature remains neutral with regard to jurisdictional claims in published maps and institutional affiliations.
Ready to submit your research? Choose BMC and benefit from:

- fast, convenient online submission

- thorough peer review by experienced researchers in your field

- rapid publication on acceptance

- support for research data, including large and complex data types

- gold Open Access which fosters wider collaboration and increased citations

- maximum visibility for your research: over $100 \mathrm{M}$ website views per year

At BMC, research is always in progress.

Learn more biomedcentral.com/submissions 